\title{
ANALISIS SOSIAL MASYARAKAT INDONESIA DALAM SASTRA CYBER EDISI 2016
}

\author{
Syifaul Fithriyah \\ MA Al-Fathimiyah Banjarwati, Paciran, Lamongan \\ HP 085732399549; Email ciplukfithry@gmail.com
}

\begin{abstract}
Abstrak: Penelitian yang bertujuan untuk (1) menjelaskan permasalahan sosial keluarga, (2) menggambarkan permasalahan sosial masyarakat, dan (3) merepresentasikan permasalahan sosial dalam sastra cyber pada Cerpen Koran Minggu edisi 2016. Metode yang digunakan dalam penelitian ini adalah kualitatif karena penelitian disini sumber datanya adalah sebuah teks sastra yang bersumber dari cerpen-cerpen Cerpen Koran Minggu 2016. Dari data tersebut penulis merumuskan permasalahan: permasalahan sosial keluarga, permasalahan sosial masyarakat, dan permasalahan sosial negara. Banyaknya permasalahan yang tergambar dalam Cerpen Koran Minggu 2016 menceritakan konflik-konflik keluarga seperti konflik antarpasutri, orang tua dan anak, hubungan masyarakat: harmonisasi bertetangga, kepedulian persahabatan, sampai kejadian sosial yang muncul di negara seperti beredarnya narkoba, perjudian, pencitraan para petinggi kita.
\end{abstract}

Kata kunci: analisis social, masyarakat Indonesia, sastra cyber

Abstract: Research aimed at (1) explaining family social problems, (2) describing social problems of society, and (3) representing social problems in cyber literature in the 2016 edition of Short Story Sunday Newspaper. The method used in this study is qualitative because the research here the source of the data is a literary text sourced from the short stories of the short story of the Koran Sunday 2016. From the data the authors formulated the problems: family social problems, social problems of the community, and social problems of the country. Many of the problems illustrated in the 2016 Newspaper Short Story tell of family conflicts such as conflicts between female candidates, parents and children, community relations: neighboring harmonization, caring friendships, to social events that arise in the country such as the circulation of drugs, gambling, imaging of our higher-ups.

Keywords: social analysis, Indonesian society, cyber literature

\section{PENDAHULUAN}

Dewasa ini, perkembangan teknologi berdampak besar pada kehidupan manusia. Jarak dan waktu tidak lagi membatasi seseorang dalam menyampaikan maupun mendapatkan informasi di era digital dan keterbukaan informasi saat ini. Hadirnya internet membuat setiap pribadi dapat membuat ruang-ruang tersendiri di dunia maya. Setiap orang bebas untuk mendapatkan berbagai macam kebutuhan dengan fasilitas yang serba mudah mulai dari hiburan, bertukar informasi, berkomunikasi, berapresiasi termasuk 
hadirnya sastra di internet, yang pada era ini disebut Cybersastra.

Fenomena sastra cyber di Indonesia agaknya membutuhkan perhatian yang lebih besar lagi karena dipercaya dapat berkontribusi bagi perkembangan kesusastraan di Indonesia. Tidak hanya itu, keberadaan sastra cyber sendiri dipercaya sebagai refleksi realitas dinamika masyarakat yang ada saat ini. Masyarakat yang senantiasa bergerak ke arah yang lebih modern ikut memberikan kontribusi bagi kemunculan sastra cyber dengan mengikuti pesatnya perkembangan teknologi komputer dan internet yang ada. Namun yang perlu digaris bawahi ialah ternyata tidak dapat dipungkiri keberadaan sastra cyber di Indonesia menimbulkan polemik tersendiri yang cukup kompleks untuk dapat dipertimbangkan bagi semua elemen masyarakat.

Banyaknya fenomena sosial diantara kita, yang kemudian menjadi sumber inspirasi bagi sastrawan dalam menghasilkan sebuah karya, terutama pada dunia cyber yang seakan-akan tanpa batasan untuk dipublikasikan. Berbeda jika harus diantrikan pada penerbit, belum tentu mendapat kesempatan untuk terpublikasi dan dibaca pecintanya. Halhal yang terjadi pada masyarakat sering tak kita sadari direfleksikan oleh penulis dalam sebuah karya sastra,Abrams (Endraswara, 2013:89), karya sastra adalah cermin kehidupan masyarakat. Karena sastra bukanla hanya sekedar hasil imajiner sastrawan, bukan sekedar hiburan waktu senggang semata. Tetapi, di dalamnya banyak fakta kehidupan yang bisa kita ambil pelajaran dan hikmahnya.Tentunya banyak masyarakat awam atau bukan penyuka sastra mengganggapnya seperti itu, dari itu peneliti tertarik meneliti tentang sastra, sebagai media perepresentasi terutama pada sastra cyber.
Banyaknya situs kelompok cyber seperti komunitas-komunitas di sosial media seperti Komunitas BisaMenulis, Komunitas Sastra Madura, Komunitas Satra Muda, Komunitas Sastra Sumba dan masih banyak lagi bahkan rata-rata pada tiap daerah ada komunitas sastra. Begitu juga situs web berjibun berdasar pecinta masing-masing. Pada komunitas itu ada yang membahas tentang apa sastra itu sendiri,iatilah-istilah pada sastra. Membahas pula mengenai kajian sebuah produk sastra, ada pula yang membahas tentang seniman, budayawan, danada juga yang berisi tentang puisi, drama, syair, dan prosa, atau membahas tentang kajian sebuah karya sastra.

Dari sastra cyber bisa kita tilik berbagai macam permasalahan sosial, mulai dari masalah keluarga, masyarakat sampai ke ranah Negara. Fakta-fakta sosial tidak luput dari jangkauan pengarang yang merefleksikan dalam sebuah alur cerita yang dibumbui imajinasi sehinggga karya tersebut apik ketika di tangan pembaca. Sayangnya tak semua pembaca bisa melihat dan memaknai sebuah karya sastra, dari itu dibutuhkan kajian dan telaah agar masyarakat awam mudah dalam memahami sebuah karya sastracyber, khususnya Cerpen Koran Minggu.

Berdasarkan paparan di atas, perlu adanya penelitian yang bertujuan untuk (1) menjelaskan permasalahan sosial keluarga dalam sastra cyber pada Cerpen Koran Minggu edisi 2016 (2) menggambarkan permasalahan sosial Masyarakat dalam sastra cyber pada Cerpen Koran Minggu edisi 2016(3) merepresentasikan permasalahan sosial dalam sastra cyber pada Cerpen Koran Minggu edisi 2016.

\section{METODE PENELITIAN}

Pada penelitian ini, penulis menggunakan metode kualitatif karena 
penelitian disini sumber datanya adalah sebuah teks sastra yang bersumber dari cerpen-cerpen Cerpen Koran Minggu sangat sinkron dengan pendapat Ratna (2015 : 47) dalam ilmu sastra sumber datanya adalah karya, naskah, data penelitiannya, sebagai data formal adalah kata-kata, kalimat dan wacana. Selanjutnya menurut Ratna, (2015: 46) metode kualitattif adalah metode yang secara keseluruhan memanfaatkan caracara penafsiran atau interpretasi dengan menyajiakn dalam bentuk deskripsi.

Data dalam penelitian ini adalah teks yang berupa kutipan kata-kata, frasa, klausa, paragraf dan wacana dari sasra cyber yakni Cerpen Koran Minggu edisi 2016. Data yang telah terkumpul diklasifikasi berdasar kebutuhan data yakni analisis sosial masyarakat yang sesuai rumusan yang ada pada penelitian ini. Analisis data dilakukan dengan analisis data kualitatif yang meliputi reduksi data, penyajian data, dan penyimpulan hasil analisis.

\section{HASIL PENELITIAN \\ DAN PEMBAHASAN \\ Permasalahan Sosial Keluarga}

Banyaknya permasalahan keluarga yang sering melintas pada setiap keluarga, selayaknya membuat kita menjadi pribadi yang lebih hati-hati dan bijak dalam menghadapi setiap permasalahan. Masalah perselingkuhan misalnya, kenikmatan sesaat yang dapat menghancurkan keluarga yang telah dibina. Biasanya kerap muncul karena permasalahan ekonomi. Harusnya diantara pasangan saling menyadari ada anak yang kerap jadi korban, sehingga tak jarang anak tumbuh tanpa kasih sayang seorang bapak misal, anak broken home, lari pada hal-hal negatif seperti seks bebas dan narkoba. Dari perekonomian pula terjadi KDRT sampai pembunuhan dalam keluarga. Di sini akan mengupas permasalahan social keluar yang ada pada sastra cyber, khususnya pada Cerpen Koran Minggu edisi 2016.

\section{Periuk Api}

Pada saat seseorag mengikat janji suci pernikahan, tentunya harus menyadari pasangan adalah kehidupannya. Kesadaran itu harus ditanam sampai akhir hayat. Pasangan baru adalah pasangan yang sedang hangat-hangatnya, bersemi, berbungabunga, rasanya dunia milik berdua apalagi dengan hadirnya si cabang bayi di perut istri, bertambahlah mekar bungabunga di rumah mereka.

Tetapi dalam indahnya bunga mawar banyak duri yang mengelilinginya, begitu juga rumah tangga yang kerap seseorang harus menahan perihnya duri yang tak kita tanam. Kita harus pandai-pandai menjaga perasaan tetangga meski kita merasakan sakitnya. Kita-pun harus pandai-pandai tersenyum meski di dalamnya menangis. Tak mudah hidup bertetangga yang tentunya berbeda karakter dan watak dengan kita, kita harus selalu mencoba menutupi segala masalah sekecil apapun yang ada di dalam rumah kita. Tanpa kita sadari, masalah sekecil debu akan menjadi batu jika sudah melalui dua lubang tetangga kita. Lubang mulut dan lubang telinga.

\section{Perempuan di Loteng Rumah}

Kalau pada cerpen pertama berbicara tentang kesetiaan, pada cerpen ini menggambarkan sebaliknya. Fenomena yang terjadi akibat masalah finansial. kewajiban seorang suami adalah sebagai pencari nafkah dalam sebuah keluarga, dan istri mendidik anak dan membantu pekerjaan rumah semestinya itu sudah dipahami oleh setiap pasangan. Tapi, dewasa ini dunia 
seperti telah terbalik banyak para istri yang bekerja. Kerja di pabrik, di kantor, di sawah bahkan kerja kasar yang tak semestinya dilakukan seorang wanita. Mungkin itu bagian dari dunia emansipasi. Emansipasi bukan berarti suami berdiam diri di rumah sebagai perempuan, yang mengerjakan pekerjaan perempuan di rumah. Mewabahnya fenomena ini sampai salah satu rumah produksi film merefleksikan dalam sebuah sinetron yang berjudul Dunia Terbalik meskipun ceritanya semi komedi tetapi sangat tersirat fakta sosial di dalamnya.

\section{Putri Raja dan Babi Hutan}

Pada cerpen ini juga menginterpretasikan kehidupan rumah tangga yang hancur karena lelaki pengangguran. Sang istri yang akhirnya menjadi seorang TKW karena tidak kuat dengan kemalasan dan kekejaman suami yang hanya menghambur-hamburkan uang untuk judi dan mabuk-mabukan.

Permasalahan sosial keluarga yang ada di sekitar kita sering kali menggambarkan akan hal ini, seorang yang terlahir dari keluarga kaya hanya bermalasan dan tidak dididik untuk mandiri oleh orang tuanya, sehingga sifat itu mendarah daging bahkan sampai kejayaannya meredup dan hartanya habis tetap ingin memerintah dan duduk santai. Selanjutnya melampiaskan segala kekesalan pada orang sekitar. Di sini digambarkan pada sosok Badri suami TKW yang bernama Ramini. Bardi adalah anak saudagar kaya, yang selalu ingin tampil parlente. Mungkin karena itu dia pemalas. Dan ketika kejayaan orang tuanya meredup dia tak menghilangkan sifat pemalasnya. Sehingga hartanya habis untuk judi, mabuk dan melunasi hutang-hutangnya kepada bank dan rentenir. Sampai hartanya benar-benar habis.

\section{Hidup Kita Selepas Elegi}

Masalah sosial pada cerpen-cerpen sebelumnya merefleksikan fakta sosial hubungan suami istri, sedangkan pada cerpen Hidup Kita Selepas Elegi ini menggambarkan korbannya, korban dari perpisahan pasangan suami istri, pertama adalah anak-anak, kedua ada orang tua mereka yang telah lanjut usia, dan yang terakhir diri mereka sendiri.

Anak yang tak lagi mendapat kasih sayang kedua orang tua sering kali lari dari perasaan tertakan, kesepian kea rah hal-hal yang negatif. Narkoba, adalah salah satu pelarian yang paling banyak digunakan orang saat merasa tertekan, bingung, capek stress. Seorang pengguna narkoba konon merasa fly, nyaman, dan indah tetapi itu hanya sementara tentunya. Selanjutnya, seks bebas. Anak remaja yang seharusnya masa senangnya bermain dan semangatnya belajar, dewasa tak lagi asing di telinga kita menghamili kawannya. Modernisasi di zaman yang serba teknologi membuat semuanya semakin mudah, tanpa didikan yang baik dan pantauan orang tua, remaja sekarang dengan mudah melihat adeganadegan seks. Dan selanjutnya mereka jadikan panutan. Bahkan anak SD-pun menjadi pelaku free seks, sampai yang berpendidikan perguruan tinggi.

\section{Duri Ibu}

Seringkali orang menyatakan, hubungan seorang anak dengan ibu kandungnya akan bertolak belakang dengan hubungan ibu mertua dengan anak mantunya. Tetapi, tidak semua pendapat itu mendekati kebenaran, hubungan baik atau buruk tentunya tergantung perorangan yang melakoninya. Bahkan ada juga, antara anak dan ibu kandung yang hubungannya buruk.

Terlebih-lebih menantu putri. Tak sedikit terjadi hubungan yang yang tak 
harmony antara seorang menantu perempuan dan ibu mertua, hal ini terjadi karena banyak hal, diantaranya menurut Ieda Purnomo Sigit Sidhi, SPsi, ketidakharmonisan tersebut timbul karena diantara kedua perempuan ada satu satu pria yang menciptakan persaingan. Mereka saling mengukur siapa yang lebih disayangi, dicintai, atau diperhatikan oleh pria yang menjadi suami (si istri) atau anak (si mertua). Psikolog tersebut juga menambahkan, secara garis besar, hal itu disebabkan oleh tiga hal: cinta, perhatian, dan finansial.

\section{Permasalahan Sosial Masyarakat}

Fenomena masalah sosial masyarakat, pada Cerpen Koran Minggu merefleksikan fakta sosial masyarakat yang bersinggungan dengan kebisaan/adat, hubungan sosial antar tetangga, antar teman.

\section{Tawa Padang Sampah}

Masa anak-anak adalah masa keemasan manusia, dimana masa menanam segala ilmu. Pada masa ini anak mudah dalam menyerap segala sesuatu. Masa bermain bersama kawan, masa belajar bersama di sekolah. Tetapi hal itu tidak untuk Carmi dan Korep, dua bocah belia yang harus menapaki jalan yang berbeda dengan teman seusianya. kala matahari belum tampak sempurna mereka harus sudah menyusuri lautan sampah bersama para pemulung dewasa lainnya, untuk mendapatkan barang berharga menurut mereka. Rongsokan, sebagai penyambung hidup.

Fenomena sosial pada cerpen Padang Sampah menggambarkan hubungan antar pemulung yang satu sama lain ada rasa kekeluargaan dan peduli. Hal itu tergambar misal, pada saat truk sampak belum dating mereka berkumpul, bercanda, saling membantu, dan saling berbagi. Saat Carmi ingin mendapatkan sesuatu yang sangat berharga, semua warga padang sampah ikut membantu unuk mencarinya. Apalagi Sopir dalim, pegawai negeri sopir truk sampah, yang sangat peduli dan khawatir dengan dua belia ini.

\section{Memoar Pesta Pernikahan}

Pernikahan, adalah suatu hal yang sangat diharapkan bagi setiap insan. Sesuatu yang sakral penuh dengan khidmad. Tentunya setiap orang menginginkan pernikahannya sempurna, tanpa kurang suatu apa. Dengan dihadiri keluarga besar, sahabat, dan tetangga. Hal yang paling penting dalam sebuah acara besar khususnya pada saat resepsi pernikahan, adalah berjalan aman dan lancar.

Begitu juga fenomena pernikahan di pulau Madura yang tergambar dalam cerpen Memoar Pesta Pernikahan. Merefleksikan acara pernikahan yang masih berpegang dengan adat dan berbau mistis. Sebenarnya hal semacam ini juga masih terjadi di daerah Jawa Timur seperti Lamongan, Tuban, Gresik dan sekitarnya. Disamping tuan rumah yang menginginkan kelancaran dan keamanan pesta pernikahannya, ada orang-orang yang ingin menghancurkannya dengan cara-cara tertentu. Misal hujan lebat, si pengantin kecelakaan, makanan jadi basi, dll.

\section{Wagimin Tikus}

Susanto menggambarkan dalam cerpennya Wagimin Tikus sangat menggelitik, mereflaksikan kehidupan di sebuah kampung yang menceritakan keakraban dengan panggilan-panggilan julukan. Itu memang kerap terjadi di desa atau kampung. Daripada di kota, tentunya panggilan-panggilan itu tak pernah ada. Tetapi panggilan tak sepadan itu bukan berarti kampungan, bukan berarti karena bodoh tak berpendidikan. Belum tentu 
yang berpendidikan tinggi kelakuannya tidak kampungan. Pada era Gusdur jadi Presiden, kata beliau orang DPR seperti anak TK. Apa yang seperti itu bukan kampungan? Mereka semua berpendidikan tinggi. Tetapi tingkahnya sangat memalukan, seperti anak TK.

Kadang orang yang kampunganlah yang merasa tinggi, merasa paling mengerti, paling tidak kampungan. Hal itu direfleksikan pada diri Pak Gun. Seseorang yang merasa terpelajar, terbaik dan tidak kampungan. Tapi naas-nya dialah yang paling kampungan.Hanya karena disebut pendatang, dia kesal. Padahal dia memang pendatang. Hanya karena sebuah julukan kepada seseorang dia-pun menganggap semua orang kampungan, padahal orang yang dijuluki tak keberatan. Dan merasa enjoy, mungkin karena sebuah julukan menjadikan keakraban diantara mereka.

\section{Seperti Ular Raksasa, tetapi dari Besi}

Banyak yang mengungkapkan jika hubungan persahabatan itu lebih abadi dari pada percintaan, lebih tulus dari padanya juga. Kadangkala rasa nyaman pada sebuah persahabatan tak pernah disangka, membutuhkan waktu lama, dan tak membutuhkan syarat. Iya, indahnya persahabatan kadang tak masuk diakal. Laksana dalam karyanya Seperti Ular Raksasa, tetapi dari Besi seakan membenarkan pendapat diatas. Indahnya hubungan persahabatan yang terjalin dari sebuah kamar rawat inap di sebuah rumah sakit, membangkitkan semangat yangmenghidupkan, meski mereka tak pernah bertemu.

Berawal dengan masuknya dua gadis remaja pasien dalam satu ruangan. Remaja yang satu mendapat tempat tidur di sebelah jendela, bermasalah dengan paru-parunya. Dia harus membuang cairan yag ada di paru-parunya dengan duduk tegak di pagi dan sore. Lima hari kemudian gadis satunya datang. Sekujur tubunya melemah, begitu pula detak jantungnya. Hanya terbaring dengan terpejam sejak hari pertama.

Gadis remaja yang di sebelah jendela tiap pagi dan sore selalu memberikan cerita kepada teman sekamarnya, meski temannya tak pernah merespon. Dia menceritakan segala sesuatu yang dilihat, dirasakan dan dialaminya.

\section{Pak Kodir}

Hidup bertetangga membutuhkan kesadaran dan saling memahami. Di antara kita ada yang kaya ada yang miskin, pekerjaan bisa ditiru tetapi rizki tidak bisa. Rizki, jodoh dan kematian sudah ada garisnya. Masyarakat kita sering tak menyadari hal itu. Pekerjaannya sama kenapa si A kaya sedang si B tetap miskin? Kita tak pernah berfikir, mungkin masakannya enak, mungkin tempatnya yang bersih, mungkin banyak berdoa dan mendekat pada Tuhan, mungkin baik pada orang lain sehingga banyak yang suka dan masih banyak kemungkinan yang lain.

Yang ada hanya berburuk sangka, dengan kemungkinan-kemungkinan yang buruk. Padahal kemungkinan yang positif, kenapa memilih yang negatif. Hanggara dalam karyanya Pak Kodir merefleksikan masyarakat kita yang kerap menghadapi sesuatu dengan terburu-buru dengan pikiran-pikiran negatif.

\section{Bandit dalam Kepentingan Cerita}

Narkoba, suatu zat yang mampu mengubah manusia. Selain mampu mengubah seseorang, narkoba juga mampu membentuk karakter manusia menjadi negatif. Peredaran dan penggunaan narkoba, belakangan ini mengkhawatirkan bangsa Indonesia. Beberapa artis Indonesia yang notaband- 
nya sebagai percontohan generasi kita banyak yang tersandung masalah penggunaan narkoba. Negara Indonesia adalah ladang empuk bagi pengedar narkoba kelas dunia. Sudah banyak WNA yang menyamar sebagai turis datang ke Indonesia untuk menyelundupkan narkoba, sayangnya rata-rata mereka bisa dengan leluasa melakukan itu dengan bantuan bandit-bandit negeri sendiri. Dan rata-rata mereka adalah pengabdi Negara ini, missal pejabat Negara, polisi, penjaga lapas, sampai tentara juga.

Fenomena permasalahan sosial Negara dalam cerpen Bandit dalam Kepentingan Cerita merefleksikan fakta sosial yang sedang merajalela di Negara kita saat ini. Kejadian yang melibatkan petugas LP Pulau Nusakambangan, penyelundup narkoba dari Australia bernama Michael JC yang bekerja sama dengan WNI yang bernama Karta Biter.

\section{Robohnya Bukit Kami}

Fenomena permasalahan sosial Negara selanjutnya mengenai kerusakan lingkungan yang diakibatkan proses tambang galian c yang terus-menerus. Tanpa berfikir akibat yang akan di dapat pada generasi mendatang. Banyaknya penambang galian c yang secara liar yang hanya memikirkan keuntungan diri sendiri tanpa memikirkan orang lain. Moehiddin menggambarkan fenomena tersebut dalam cerpennya Robohnya Bukit kami.

Banyaknya kerusakan lingkungan di Negara kita, tanpa kita sadari adalah tangan-tangan kita sendiri yang merusaknya pengerukan pasir yang besar-besaran dilakukan dapat mengakibatkan abrasi, penggundulan hutan tanpa penanaman kembali juga akan berdampak kekeringan, kebakaran saat kemarau, banjir dan longsor saat hujan tiba. Tentunya kejadian sudah taka sing lagi di negeri ini. Banjir longsor melanda di mana-mana saat musim hujan tiba. Tapi sebaliknya kekeringan air, kebakaran, polusi terjadi saat kemarau datang. Ini adalah PR terbesar pemerintah Indonesia bagaimana cara mengatasi ini semua, tetapi bukan hanya pemerintah tapi selayaknya msyarakat juga menyadari ini semua.

\section{Pagar Ayah}

Baru-baru ini masyarakat Indonesia dibuat heboh dengan munculnya berita tentang group facebook yang yang beranggotakan pelaku pedofilia. Group yang bernama Official Candy's Group, tetapi ada grup yang bernama sama, bukan pelaku pedofil, tetapi anti pedofil. Mungkin setelah terkuaknya kasus ini ke massa, grup tersebut diblokir dan berubah fungsi. Dalam website Bombastics, ternyata selama ini OCG sudah digunakan untuk wadah berbagi gambar dan video dengan konten pornografi anak. Parahnya lagi group yang dibuat oleh pria asal Jawa Timur itu ternyata berjejaring dengan kelompok lain di negara-negara asing.

\section{Pertunjukan Menyapu Jalan}

Pencitraan, tentunya bukan hal yang asing di negeri kita. di kalangan para pejabat tentunya itu sebagai sebuah yang wajib dilakoni untuk membersihkan, mengindahkan nama. Seorang pejabat, seperti wali kota tentu ingin namanya selalu bersih dari keburukan, ingin selalu dielu-elukan namanya, dan dicintai rakyatnya.

Feng Jicai dalam karyanya
Pertunjukan menceritakan perjalanan seorang wali kota dan tugasnya. Di mana seorang wali kota selalu ingin terlihat sebagai teladan meski kadang itu hanya luarnya saja. Dalam sebuah acara "Minggu BersihBersih Nasional", sang wali kota rela menghadiri acara tersebut sebagai contoh 
anak buah dan rakyatnya. Orang besar seperti pejabat selalu mendapat pelayanan yang lebih dibanding orang biasa, tentunya itu menimbulkan rasa, rasa tinggi, rasa dihormati dan rasa sebagai orang besar.

\section{Judi Kodok-Kodok}

Pada cerpen kali ini merefleksikanIndonesia di masa orde baru. Masih tentang watak orang Indonesia yang bermental terjajah. Judi Kodok-Kodok karya Alexander menggambarkan kebebasan sebuah kempung dalam berjudi sampai mendarah-daging pada diri mereka. Segala macam judi ada di sini, tapi tentunya semua itu tak akan mulus tanpa adanya suap. Orang Indonesia yang menyukai semua dengan instan, seperti lotre, dan judi yang lain, mulai taruhan paling kecil sampai yang berjumlah milyaran. Sampai detik ini pun mental itu masih melekat pada orang Indonesia. Sampai sekarang masih sering ditemukan pagelaran judi, semua hal dijadikan taruhan. Dari adu ayam, pemilihan petinggi mulai dari desa sampai Negara, tontonan sepak bola dll.

\section{SIMPULAN DAN SARAN}

Berdasarkan hasil penelitian dan pembahasan pada bab empat, di peroleh simpulan bahwa analisis sosial masyarakat Indonesia dalam sastra cyber khususnya pada Cerpen Koran Minggu edisi 2016 yang telah diambil sampel sebagai berikut. Pertama, ada beberapa masalah sosial keluarga, dalam teks Cerpen Koran Minggu 2016 terdiri dari; orang ketiga dalam hubungan suami istri, masalah ekonomi dan KDRT yang kerap merusak rumah tangga, broken home akibat dari perceraian orang tua, dan hubungan antara menantu perempuan dan ibu mertua. Kedua, Permasalahan yang ditemukan dalam masalah sosial masyarakat dalam teks Cerpen Koran Minggu 2016 yaitu: kepedulian dan persahabatan antar pemulung, hubungan masyarakat dengan sebuah adat pernikahan, hubungan orang kota dengan orang kampung, dan ketulusan persahabatan dan antar tetangga yang tak pernah disadari membawa dampak positif. Ketiga, Masalah-masalah yang terlihat dalam masalah sosial Negara, pada Cerpen Koran Minggu 2016 yakni: narkoba dan suap di Indonesia, rusaknya lingkungan kita, penyakit pedofilia, dan Penciteraan para pejabat

\section{DAFTAR PUSTAKA}

Anwar, Ahyar. 2012. Teori Sosial Sastra. Yogyakarta : Ombak.

Arikunto, Suharsimi. 2013. Prosedur Penelitian : Suatu Pendekatan Praktik. Jakarta : Rineka Cipta.

Astika, I Made dan I Nyoman Yasa. 2014. Sastra Lisan : Teori dan Penerapannya. Yogyakarta : Graha Ilmu.

Damono, Sapardi Djoko. 1980. Sosiologi sebagai Pengantar Ringkas. Jakarta : Departemen pendidikan dan Kebudayaan.

Departemen Pendidikan Nasional. 2005. KBBI : Edisi Ketiga. Jakarta : Balai Pustaka. . 2013. Teori Kritik Sastra : Prinsip Falsafah dan Penerapan.. Yogyakarta : CAPS (Center for Academic Publishing Service).

Kurniawan, Heru. 2012. Teori, Metode, dan Aplikasi Sosiologi Sastra. Yogyakarta: Graha Ilmu.Yogyakarta : Graha Ilmu.

Ratna, Nyoman Kutha. 2015. Teori, Metode, dan Teknik Penelitian Sastra. Yogyakarta : Pustaka Pelajar. 